\author{
Marek Tatar \\ Cardinal Stefan Wyszyński University in Warsaw \\ ORCID: $0000-0003-4271-8478$
}

\title{
Communal and Community-Forming Character of Prayer $^{1}$
}

\begin{abstract}
In the age of secularisation, prayer is becoming an increasingly difficult act of believers to understand. Extremely dangerous individualism and subjectivism is the contemporary threat to common and community prayer. All of this makes it necessary to take a new look at this category of prayer so that it leads to an authentic testimony from Christians in the world. In this way, it also prevents the dangerous exclusivity of believers themselves when faced with challenges.

Among the whole variety and categories of prayers, communal prayer and the prayer of community are very important. This distinction is necessary because it reveals to us the truth that every prayer has a communal character even though it is not always a common prayer. However, prayer celebrated together is the source of life for the Christian, the Church and the clearest and most readable testimony of faith.
\end{abstract}

Keywords: prayer, community, liturgy, formation, spirituality

\section{Introduction}

The problem of prayer is one of the key issues in the theology 1 of Catholic spirituality, but also in the practical dimension of Christian life and spiritual development. It should be stated that prayer is a source, a means, but also a kind of test of the dynamics of one's development in the faith, and thus of the spiritual

${ }^{1}$ The present article is a corrected and supplemented version of the text originally published in Polish: Marek Tatar, "Wspólnotowy i wspólnototwórczy charakter modlitwy," Collectanea Theologica 89 (2019) no. 3, 111-136. Translated from Polish by Maciej Górnicki. 
development of the Christian. In fact, no religion can be indicated which would not take this aspect into account. Of course, in the whole diversity of religions, as well as of denominations, we have different understandings of its essence and it also takes on different dimensions, forms and character. Nevertheless, it always remains a constant phenomenon, because it touches on the relationship between man and the person of God and is not only its expression, but also creates and develops it. Christianity emphasises, above all, its relational-personalist nature, which means that it is, on the one hand, a gift that man receives from God and, at the same time, it becomes a response to His initiative. For this reason, its dialogic and communal character must be emphasised. The phenomenon of prayer demands its constant reworking in the context of cultures and civilizations. This means that it is constantly being brought up to date, still preserving its identity. The very essence of Christian prayer does not change, but there is a change in the way it is expressed. It is also worth noting that its character in relation to a particular person depends primarily on the stage of his or her spiritual development, as all theologians note and emphasise. One of its dimensions is the communal character. Looking at prayer in this context makes it necessary to emphasize a certain contemporary crisis of understanding and experiencing community against the background of dangerous individualistic tendencies. Next, attention should be paid to the essence of this kind of prayer in order to show its practical dimension.

\section{Fundamental Understanding of Community and Communal Dimension}

The source of human origin is the community of Divine Persons. Man lives his earthly stage of life in a community and ultimately his aim is to be unified with God - Community. ${ }^{2}$ An analysis of the very

\footnotetext{
${ }^{2}$ Cf. H. Urs von Balthasar, Teologika. Duch Prawdy, vol. 3. transl. J. Zychowicz, Kraków 2005, p. 378. "[...] nature has always been subject to grace, and the time granted to creation is granted to it from the eternally triune time and the eternally triune history of God"; A. Scola, Osoba ludzka. Antropologia teologiczna, transl.
} 
structure of man reveals his vocation to exist as a social being. The vocation to existence therefore has a communal and community-forming character. ${ }^{3}$ The proper key to the understanding of this dual dimension of man, i.e., his individuality and at the same time his communal dimension, is the proper definition of community. The encyclopaedic formulations indicate its multiple aspects and complexity. The definition of community itself and communal dimension depends on the academic field which tries to define it as well as the characteristic constitutive elements of a community which are considered essential. K. Mielcarek states

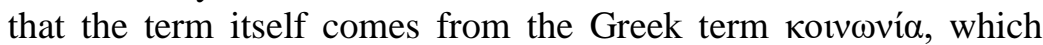
should be translated into Latin as communio, communitas and congregatio. ${ }^{4}$ Referring to the Latin dictionary we will find the term communio defined as "joint membership, participation, community." 5 Following the attempts at clarification made by Fr. M. Jagodziński, we notice that a double metaphorical connotation should be taken into account, i.e. referring to the core "mun" meaning a call which gathers people oriented towards each other and "munus" meaning a task, ministry, gift, refreshment, mutual commitment to serve. Originally, as the theologian notes, based on 1 Cor 10:16 and 2 Cor 13:13, it meant having a share in Jesus Christ and in the work of the Holy Spirit. ${ }^{6}$

L. Balter, Poznań 2005, p. 56-57; L.F. Ladaria, Wprowadzenie do antropologii teologicznej, transl. A. Baron, Kraków 1997, p. 41-44. The author states: "If the God who saves man is the One and Triune God, then also the One who creates him is the One and Triune God [...]"

${ }^{3} \mathrm{Cf}$. Pastoral Constitution on the Church Gaudium et spes, 23, 24. The second point of the Church's teaching is very clear: "God, who surrounds everything with fatherly care, wanted all people to form one family and relate to each other in a spirit of brotherhood. For all of them, created in the likeness of God, who 'from one man brought forth all mankind to dwell on the whole surface of the earth' (Acts 17:26), are called to one and the same end, that is, God himself."

${ }^{4}$ Cf. K. Mielcarek, Wspólnota, in: Encyklopedia katolicka, vol. XX, Lublin 2014, col. 999.

${ }^{5}$ Communio, in: Słownik łacińsko-polski, ed. J. Korpanty, Warszawa 2001, p. 126

${ }^{6}$ Cf. M. Jagodziński, Sakramenty $w$ stużbie communio, Warszawa 2008, p. 7; R. Skrzypczak, Kościół jako misterium, communio i missio, "Warszawskie Studia Teologiczne" XVII (2004), p. 175. 
An attempt of definition deeply rooted in the Holy Scripture leads to the theological characterization of community. As Fr. A. Nadbrzeżny claims, "it means a union of persons based on authentic and deep inter-subject relationships (communio personarium). ${ }^{7}$ This character of person is the result of its individual and at the same time social character.

The Catholic ethical approach, based on St. Thomas Aquinas, emphasises above all the permanence of the union of persons, which has a moral character, and which aims, through common action, at a decent goal. Following the Aristotelian scheme of matter and form, it is stated that the matter is constituted by a multiplicity of persons and the form - by moral union based on "unity of minds, will and powers." ${ }^{8}$ In turn, the ethicist Fr T. Ślipko emphasizes first of all the goal as a constitutive element, recognized and giving community a direction. ${ }^{9}$

In the psychological and social sciences, and especially in the sociological sciences, a community is understood as a certain population or social group, based on internal bonds, as well as a structure with which the members of the community identify themselves, acceptance of a certain common hierarchy of values and goals of a superior character. This understanding of community assumes the relationship that exists between the members of a certain community based on cultural, geographical, and political background. From a sociological point of view, a person belonging to a community is subject to the process of socialisation, referring to the characteristics and goals of a given community. On this basis, the following categories of community can be distinguished: national, family, religious, cultural, state, inter-state, universal. ${ }^{10}$

\footnotetext{
${ }^{7}$ A. Nadbrzeżny, Wspólnota. W teologii, in: Encyklopedia katolicka, op. cit., col. 1000 .

${ }^{8}$ T. Ślipko, Zarys etyki szczegółowej, vol. 2. Kraków 1981, p. 122.

${ }^{9}$ Cf. ibid.

10 Cf. L. Cynarzewska-Wlaźlik, Wspólnota. W naukach społecznych, in: Encyklopedia katolicka, op. cit., col. 1001-1002; B. Mikołajewska, Zjawisko wspólnoty, New Haven 1999, 11-78. As a sociologist, the author undertakes the study of sociological concepts concerning the phenomenon of community. In this publication we have presentations of the concepts of: C. Bell and H. Newby,
} 
In its research, psychology focuses primarily on the mental elements that socialise the individual, as well as the influence of the community on the way an individual is psychologically integrated. The studies are largely concerned with so-called social psychology. It combines psychological and sociological theories. It touches upon such issues as: conformism, labelling, nonconformism, the character of the group (youth, professional, academic, etc.) It emphasizes mainly such elements as: membership, the principle of identity, centres of focus, goals and tasks, group structure. A very serious area of research is social exclusion: the way it happens, the attitudes, reasons, identity of the rejecting person, presence or lack of social support, inclination to reflection related to rejection, the way of interpretation, reasons for rejection, responsibility for the situation, the degree of the experience of rejection. ${ }^{11}$

Against this background, a very clear picture of a communal dimension understood in terms of spirituality appears. It is, above all, man's relationship with the person of God. It has a fundamental character and creates a basic community of man in relation to oneself and in relation to another human being who is one's equivalent in terms of personality and subjectivity. ${ }^{12}$ The phenomenon of man's openness to community should therefore be highlighted, as a result of which he does not remain a nomad or a closed, self-sufficient individual. We are then talking about self-transcendence towards the "other." 13 We cannot limit this self-transcendence to the practical

R.A. Nisbet, Ch.H. Cooley, E. Faris, H.J. Gans, L. Warren, P. Saunders, D. Rose, D.B. Clark. At the same time, the author tries to study a community in relation to religion. She presents in this analysis the approaches of: J.D. Hunter, J.H. Fichter, B. Wilson, Barbara Lewenstein, as well as contemporary phenomena of social transformation and the place of community in terms of the community in: P.L. Berger, B. Berger, H. Kellner, R.A. Nisbet.

${ }^{11}$ Cf. M. Piłat-Borcuch, Pomiędzy tożsamościa osobowa a postawa społeczna, "Zeszyty Naukowe Politechniki Śląskiej," 2013, no. 65, p. 317-327.

${ }^{12} \mathrm{Cf}$. Pastoral Constitution on the Church Gaudium et spes, 23.

${ }^{13}$ Cf. S. Kowalczyk, Zarys filozofii człowieka, Sandomierz 1990, p. 204; M. Tatar, Od duszy artysty do artyzmu ducha, "Collectanea Theologica," 84 (2014) no. 1, p. 121. The analysis of the phenomenon of community and self-transcendence towards the "other" became the basis of the whole work built by St. Brother Albert. By emphasizing the importance of poverty, it indicates that freedom in every area 
dimension alone, but man sees this need in relation to an attempt to answer the basic and fundamental question concerning his temporal and ultimate existence.

This issue also requires a look at the relationship between the individual and the community, because, as has been shown, there is an inextricable relationship between the two realities. The individual is not a standalone nomad, but neither can the community depersonalize or depreciate the individuality of the entity. As Fr. Prof. S. Kowalczyk claims, following the approach of K. Wojtyła in his work The Acting Person, we are dealing with a variety of models of this relationship. He considers three to be the most representative ones, i.e., collectivism, extreme individualism and personalism. He considers the first two to be degenerations that treat the relationship between the individual and society in an extreme way. The first one is reductionist and leads to the obliteration of the person's individuality, at the same time absolutizing collectivism. Its classic representative is Marxism. The second, of a liberal nature, leads in turn to absolutizing the individual. Its genesis is to be found in the theory of atomism and nominalism. The representatives of this trend often listed include: Thomas Hobbes, John Locke, Jean Jacques Rousseau. ${ }^{14}$ An extreme approach is found in Jean Paul Sartre, who considers one's "neighbour" to be a denial of my "self," questioning my subjectivity. ${ }^{15}$

Reaching for the personalistic solution allows us to solve the problem in a realistic way. Fr. Prof. W. Granat suggests that the description of a specific community is a much simpler task, while it is more difficult to show what its essence is. Therefore, it becomes necessary to refer to the sociological sciences. He assumes that if it were possible to precisely answer the question about the essence of the community and the individual in their mutual relationship, sociology would prove to be an unnecessary field. In turn, the very answer to the question about the essence of society would make it

of human life allows a person to achieve this autotranscendence towards both God and man.

${ }^{14}$ Cf. ibid., p. 280.

${ }^{15}$ Cf. J.P. Sartre, L'être et le néant, Paris 1943, p. 26, 310-364. 
possible to determine exactly who a person is. ${ }^{16}$ Ultimately, by analysing the issue and referring to E. Mounier, the social science of the Church and her documents, he concludes that: "A person dominates the community by his or her ultimate calling, but achieves his/her salvation in the community of the People of God. Here we have a model of harmony in individual and social life". ${ }^{17}$ In turn, the already mentioned ethicist, Fr. Prof. T. Ślipko, proposes a solution to the apparent, in his opinion, conflict between human individuality and his socialisation. He notes that man is a psycho-physical entity and also an individual. We also note that he is at the same time a being that is turned towards others in his relationship. It should therefore be stressed that, as an individualised substance, man is an autonomous entity. Relationship with others stems from an ontological need that is inherent in human nature. The other person is a good that corresponds to human nature and therefore man transcends himself towards the other person. In conclusion, Ślipko concludes that individuality and socialisation are two different ontological categories that exist in human nature, which results in compatibility and differentiation at the same time. ${ }^{18}$

The importance of the individual's relationship to the community also reveals mutual dependence and influence. Undoubtedly, in contemporary reality, we are witnessing a rather extreme approach to the individual and, at the same time, a depreciation of community and the opposite process. This fact is rooted in the entire human culture in its broad sense. The Church has made this point in a very clear and unambiguous way in her teaching: "what is man? About himself he has expressed, and continues to express, many divergent and even contradictory opinions. In these he often exalts himself as the absolute measure of all things or debases himself to the point of despair. The result is doubt and anxiety."19 This fact of "imbalance" was noted and analysed by John Paul II in his Apostolic Exhortation Ecclesia in Europa. The Pope sees this "imbalance" above all in sin

16 Cf. W. Granat, Personalizm, Personalizm chrześcijański. Teologia osoby ludzkiej, Lublin 1982, p. 545.

17 Ibid., p. 549.

${ }^{18}$ Cf. T. Ślipko, Zarys etyki szczegółowej, op. cit. p. 15-116.

${ }^{19}$ Second Vatican Council, Pastoral Constitution on the Church in the Modern World Gaudium Et Spes, 12. 
and in the fact that man has departed from God, thus losing the right point of reference. Treating the person of Jesus Christ in terms of the past tense has resulted in a loss of hope, and thus man has become the point of reference for himself. ${ }^{20}$ This imbalance caused by the promotion of anthropology without Jesus Christ led to the emergence of ideologies and practical attitudes and behaviours of an extremely egocentric, individualistic and subjective nature. ${ }^{21}$ Following the thought of Pope Benedict XVI, it should be stated that we are indeed dealing with a dictatorship of relativism, which undermines the objective legitimacy of the truth. ${ }^{22}$ The attack of secularism has led to the undermining of the basic community, which is the family. ${ }^{23}$ In this way, in the whole process of formation and education based on faith, which is inextricably linked to prayer, we are dealing with a serious distortion of the understanding of its communal dimension.

\section{Communal and Common Prayer}

In order to perform a proper analysis of this kind of prayer it is necessary to outline the nature of prayer in the general sense. This proves to be a complex task, due to the diversity of conceptions, approaches, as well as the fact that theologians and masters of

20 Cf. John Paul II, Post-Synodal Apostolic Exhortation Ecclesia in Europa (henceforward EE), 28.06.2003. The Pope, referring to the Second Special Assembly of Bishops, which was dedicated to Europe, states: "Among the aspects of this situation, so many of which were frequently mentioned during the Synod, I would like to mention in a particular way the loss of Europe's Christian memory and heritage, accompanied by a kind of practical agnosticism and religious indifference whereby many Europeans give the impression of living without spiritual roots and somewhat like heirs who have squandered a patrimony entrusted to them by history. It is no real surprise, then, that there are efforts to create a vision of Europe which ignore its religious heritage, and in particular, its profound Christian soul, asserting the rights of the peoples who make up Europe without grafting those rights on to the trunk which is enlivened by the sap of Christianity". ${ }^{21}$ Cf. ibid., 8-9.

22 Cf. J. Warzeszak, "Dyktatura" relatywizmu $w$ ujęciu Benedykta XVI, "Warszawskie Studia Teologiczne" XXIV (2011) no. 1, p. 291-322; R. de Mattei, Dyktatura relatywizmu, transl. P. Toboła-Pertkiewicz, E. Turlińska, Warszawa 2009, p. 23-48.

${ }^{23}$ Cf. EE 8. 
spiritual life emphasize elements special for them, which they consider essential and constitutive. Fr. A. Słomkowski, when dealing with this issue, made a list of the most important terms which have an impact on the formation of the theology of prayer. For St. Gregory of Nyssa it "is communion, or conversation with God," according to St. Augustine "prayer is a thought of God with a pious and humble heart," St. John Climacus claims that "prayer is the communion and union of man with God," while St. John of Damascus defines it in the following words: "It is the elevation of the soul to God" and "a request made to Him for the right things." ${ }^{24}$ Z. Nabzdyk claims that the definition of Evagrius of Pontus, who describes it as the elevation of the spirit to God, should be marked as one of the relevant definitions. As the author of the study points out, here is the origin of the definition which was adopted by the West and which is attributed to St. John of Damascus. In his study, Fr. Prof. S. Urbański, on the other hand, very clearly points to St. John of Damascus, quoting specifically his words, that prayer is: "the elevation of the soul to God." He based his conclusions on numerous studies in this respect, and above all on the work of St. John of Damascus himself, De fide orthodoxa (cf. 3, 24; PG 94, 1089). ${ }^{25}$ In turn, St. Thomas Aquinas states that in prayer we are dealing with the ascension of man to God with the active function of the human mind. ${ }^{26}$ To the above mentioned definition attempts, we should add the approach of St. Theresa of Avila, who actually based the whole scheme of the dynamics of the spiritual life on the development of prayer. In her writings we find the following expression: "prayer is nothing else, but being on terms of friendship with God, frequently conversing in secret with Him Who, we know, loves us." 27

\footnotetext{
${ }^{24}$ Cf. A. Słomkowski, Teologia życia duchowego, Ząbki 2000, p. 199.

${ }^{25}$ Cf. S. Urbański, Teologia modlitwy, Warszawa 1999, p. 26.

${ }^{26}$ Cf. STh II-II, 83, 17. ,Oratio rationis est actus, applicantis desiderium voluntatis ad eum, qui nin est potestate nostra sed supra nos, sciliced Deum" (Prayer is an act of reason that directs the desire of the will to the one who, not subject to our power, is above us, that is, God).

${ }^{27}$ Santa Teresa, Libro de la Vida, in: Obras completas (ed.) T. Álvarez, Burgos 2014 , c. 8,7 . „que no es otra cosa oración mental, a mi parecer, sino tratar de amistad, estando muchas veces tratando a solas con quien sabemos nos ama”.
} 
Referring to contemporary theologians, it is worth emphasising K. Rahner's approach in this respect. Rahner emphasizes such elements as: the natural and supernatural reference of man to God, the encounter of human reality with the mystery of God, man's response in an attitude of humility and disposition towards God, value-oriented acceptance of all conscious religious acts. In turn, by emphasising that this is a gift from God and, at the same time, an action of man, J. Subrak emphasises the dialogical character of prayer. ${ }^{28}$ For R. Guardini, the definition of prayer boils down to the comprehension of the relationship between "me" and "You." However, it should be stressed that it is necessary to define the relationships, because of their diversity and the resulting discrepancies. ${ }^{29}$

To conclude this presentation, we should refer to the interpretation of Church's teaching contained in the Catechism of the Catholic Church. It defines prayer in the following words: "Prayer is the raising of one's mind and heart to God or the requesting of good things from God," ${ }^{30}$ and at the same time

${ }^{28}$ Cf. Z. Nabzdyk, Modlitwa-źródło i wyraz duchowości, in: Teologia duchowości katolickiej, ed. W. Słomka, M. Chmielewski, J. Misiurek, A.J. Nowak, Lublin 1993, p. 125; W.R. Macko, Rola $i$ znaczenie modlitwy $w$ życiu świeckich $w$ świetle nauczania kard. Stefana Wyszyńskiego, "Collectanea Theologica” 76 (2006) no. 1, p. 94. The author states: "Man, through prayer, is able to properly evaluate his actions and relate them to God, the giver of all goods."

${ }^{29}$ Cf. R. Guardini, Vorschule des Betens, Leipzig 1960, p. 209; K. Góźdź, Teologia człowieka, Lublin 2006, p. 205. K. Góźdź notes that the relationship to God, who enters into personal contact with man, leads to a community of faith. Religiousness is a manifestation of social life realized not only on the level of interpersonal contact, but in terms of the experience of faith it is also a socialization directed towards a dialogical contact with God. This is how the crossing of human materiality towards transcendence is realised. It is the "I" seeking the absolute "you" resulting from an ontological need. M. Jagodziński, Communio dzięki komunikacji. Teologiczny wymiar teorii komunikatywnego działania w eklezjologii Medarda Kehla SJ, Radom 2002, p. 18-23. The author emphasises that the development of a religious life characterised by the dynamism of faith introduces man into a communicative way of the human person's existence with the person of God. In this way the communal dimension of the Church is constituted, which in M. Kehl's understanding is the "sacrament of the communion of God."

${ }^{30}$ Catechism of the Catholic Church (henceforward CCC), 2559. 
indicating that it is a gift from God, a covenant, and a communion. ${ }^{31}$ From the point of view of the issue we discuss, the latter aspect in particular is extremely important. Therefore, the essential importance of the addition should be stressed: "Prayer is Christian insofar as it is communion with Christ and extends throughout the Church, which is his Body. Its dimensions are those of Christ's love." 32 This means that it is a pursuit of unity with Jesus Christ, while at the same time building a supernatural and visible community with Him.

The analysis of prayer reveals the variety of its types. These divisions result from the criteria applied, i.e., its content (request, praise, thanksgiving and propitiation), the way prayer is formulated, expressed or practised (oral, mental) and the forms of practice (public or liturgical, communal, individual). In this analysis we are particularly interested in community prayer. Referring to the biblical foundations, both the Old and the New Testament, ${ }^{33}$ we can find numerous examples. Reading the Gospel shows very clearly the very attitude of Jesus Christ who prayed (cf. Lk 6:12; 9:18-20; 22:32.42; Mk 1:35; Jn 11:41-42; 17:6-26) but who also teaches the apostles to pray (cf. Lk 11:1-4). ${ }^{34}$ All these moments find their culmination in the words of Jesus Christ: "[...] truly, I say to you, if the two of you on earth agree to ask for something, then everything will be lent to them by my Father, who is in heaven. For where there are two or

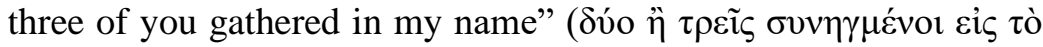

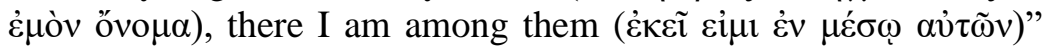

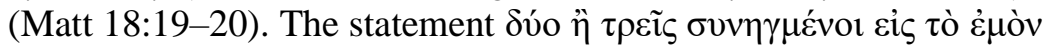
óvo $\mu \alpha$ is worth emphasising, as it underlines the communioncreative character of prayer and at the same time clarifies its essential motif. Equally important is the further statement $\dot{\varepsilon} v \mu \varepsilon \dot{\varepsilon} \sigma \omega$ $\alpha \cup \tilde{\omega} \tilde{v}$, which points to the nature of Christ's presence. This means that by its nature, prayer is communal, because unity with Jesus

${ }^{31}$ Cf. ibid. 2560-2565; A. Zuberbier, Korzenie i natura modlitwy chrześcijan wedtug "Katechizmu Kościoła Katolickiego", "Collectanea Theologica," 65 (1995) no. 2, p. 37-38.

${ }^{32}$ CCC 2565.

${ }^{33}$ Cf. Z. Nabzdyk, Modlitwa - źródło i wyraz duchowości, op. cit., p. 126-127;

D. Wider, Zawszeę módlcie, Kraków 1999, p. 13-16.

${ }^{34}$ Cf. D. Wider, Zawszę módlcie, op. cit., p. 39-40. 
Christ gives rise to the essential character of communion with Him. For this reason, we can speak of prayer lived individually by man, but it is never private and cannot be reduced to the level of man himself. ${ }^{35}$ In this context we observe the importance and significance of the ecclesial dimension of prayer, since the Church constitutes a communion based on the presence of Jesus Christ as its Head (cf. Col 1:18; Eph 4:11-16). Following St. Thomas Aquinas, we find that both the Head is one with the members, and that this bond applies to those who belong to Christ and the Church. ${ }^{36}$ This also makes every Christian's prayer communal in character and it takes place in the entire community of the Church, that is to say, in the presence of the saints and the blessed, those who are in Purgatory and the living.

Referring to the attempts to define "communal" prayer, which seems to be a more appropriate term than the word "collective" 37 used by Fr. M. Chmielewski it should be noted that the authors apply a two-fold argumentation, i.e. theological, which was signalled above, as well as social and anthropological, on the grounds that man, by his nature, is an animal sociale. ${ }^{38}$ Unfortunately, in many cases a rather serious mistake is made and communal prayer is identified with common prayer. As has already been pointed out, every prayer has a communal character, while not every prayer is said together. Communal prayer touches first and foremost on fundamental principles and motives. On the subject of common prayer, an attempt will be made to present its character and meaning. Fr. J. Gogola, when categorising prayers, recognises communal prayer as a dimension of liturgical prayer. ${ }^{39}$ It is not entirely possible

\footnotetext{
${ }^{35}$ Cf. J. Gogola, Teologia komunii z Bogiem, Kraków 2001, p. 290-291.

${ }^{36}$ Cf. STh. III, 48, 2, ad 1; W.R. Macko, Rola $i$ znaczenie modlitwy $w \dot{z y c i u}$ świeckich, op. cit., p. 96. The author describes this relationship in the following words: "Prayer, as an expression of the relationship between creation and the Creator, is the recognition of the fullness of dependence and subordination in the dynamic sphere. With this in mind, man carries out his tasks not in order to realise the intended plan, to gain a livelihood or to obtain someone else's favours, but because it has value before God."

${ }^{37}$ Cf. M. Chmielewski, Vademecum duchowości chrześcijańskiej, Lublin 2004, p. 176.

${ }^{38}$ Cf. Z. Nabzdyk, Modlitwa - źródło i wyraz duchowości, op. cit., p. 131-132.

${ }^{39}$ Cf. J. Gogola, Teologia komunii z Bogiem, op. cit., p. 304.
} 
to agree with such categorization. Liturgical prayer can be performed individually as well as together, i.e., in a group of praying people, but it always has a communal character. However, communal prayer does not always have to be liturgical. The Church knows and practices many forms of extra-liturgical prayer, celebrated either in community or individually. The importance of both the communal prayer itself, as well as a clear specification of this category, can be found in the approach of Fr. Prof. J. Misiurek, who points out that the prayer of the Liturgy of the Hours as well as the Eucharist has exceptional importance. ${ }^{40}$ Unfortunately, the analysis of the theologian from Lublin has been narrowed down to documents concerning the communal character of liturgical prayer and sometimes he confuses it with common prayer. Moreover, there is a sense of limitation, as the analysis of this issue is narrowed down to the consecrated and priestly life. ${ }^{41}$ The communal character of prayer concerns every form of life and highlights the essential element of sanctifying life in relation to the universal vocation to holiness, which was so strongly advocated by the Second Vatican Council. ${ }^{42}$ It is precisely the communal dimension, which has a supernatural, Christocentric, pneumatological and deeply ecclesial character, that is the keystone of the whole praying Church - the Community.

Common prayer is a very important category, which can be a certain component of communal prayer. This type of prayer concerns and describes a community of people who pray, which has a concrete character, and which is realised in the community of the whole Church. This specification is necessary because of the fundamental difference. It is worth highlighting the assurance that Christ has left regarding the effectiveness of such prayer: "Again I say to you, if two of you agree on earth about anything they ask, it will be done for them by my Father in heaven" (Matt 18:19). The practice of the Church of the first centuries has very clearly emphasized this way of prayer, which has a community-forming and

\footnotetext{
${ }^{40}$ Cf. J. Misiurek, Modlitwa. Medytacja. Mistyka, Lublin 2011, p. 159.

${ }^{41}$ Cf. ibid., p. 167-171.

${ }^{42}$ Cf. Dogmatic Constitution on The Church Lumen Gentium (henceforward LG), 39.
} 
Church-forming dimension. St. Thomas Aquinas acknowledged the special character of this prayer, stating that its effectiveness concerns not only the living but also sinners who have ended their mortal life in such state..$^{43}$ Following the theology of the Christian East, we can say that it has a cosmic character and dimension. However, John Climacus, speaking in this spirit and having the experience of the desert, concludes: "If you sing in church with a large number of people, it will be difficult for you to make your prayer spiritual and separated from any image and sensory experience. ${ }^{\prime 44} \mathrm{He}$ also stresses the real danger of vanity, distractions and lack of concentration, as well as disorder in the very collective exercise of prayer. ${ }^{45} \mathrm{John}$ Chrysostom, in turn, points out: "One can pray in one's own home, but one cannot pray as well as in the church [...] Here, unanimity and consensus reign, the bond of love and prayers of priests. The presence of priests serves this purpose: the prayers of the community are weaker and they join the prayers of the priests, which are stronger, and all rise to heaven together." 46

Referring to the Instruction on Contemplative Life and Enclosure of the Nuns of the Congregation for Institutes of Consecrated Life and Societies of Apostolic Life Venite seorsum we find an extremely important statement: "Their prayer, especially their participation in the Eucharistic Sacrifice of Christ and the celebration of the sacred office, is the fulfilment of the greatest task of the community of prayers, which is the Church, namely the worship of God." ${ }^{47}$ Similarly, Liturgy of the Hours is defined by its Introduction, stating that this daily prayer of the Church has a community-forming character. In this way, not only is worship exercised in a particular community of believers, but at the same time it is an extremely important means of formation. It demands the renunciation of one's individualism, but also submission to the prayerful order that results from the schedule of a religious day, a priestly day, or marriage and

\footnotetext{
${ }^{43}$ Cf. STh II-II, q 83, a. 7.

${ }^{44}$ John Climacus, Scala Paradisi, 18, 7 PG 8, 937 d.

${ }^{45}$ Cf. ibid., 4, 91, 713 d.

${ }^{46}$ John Chrysostom, De incomprehensibili dei natura 3, PG 48, 726.

${ }^{47}$ Congregation for Institutes of Consecrated Life and Societies of Apostolic Life, Instruction: Instruction on Contemplative Life and Enclosure of the Nuns Venite seorsum, Rome 15.08.1969, 3.
} 
family life. We find a very clear statement in the next instruction of the Congregation for Consecrated Life and Societies of Apostolic Life Congregavit nos in unum Christi amor: "Prayer in common, which has always been considered the foundation of all community life, starts from contemplation of God's great and sublime mystery, from wonder for his presence, which is at work in the most significant moments of the life of our religious families as well as in the humble and ordinary realities of our communities." 48 At the same time, we note that common prayer does not contradict other forms of prayer, but on the contrary is internally and externally coherent with them. ${ }^{49}$ John Paul II confirms this position, referring to the practice of the Church from its beginnings and emphasizing the importance of this prayer for the authentic development of the community of life. ${ }^{50} \mathrm{He}$ sees in it the basis of a true communion life. ${ }^{51}$

Following the thought of Fr. S. Urbański, it should be stressed that love is the basis and at the same time the deepest motive for communion union in prayer. First of all, it is directed at God, to whom each of those who take part in the prayer turns. Then it is necessary in interpersonal relationships. In this way, prayer, which

${ }^{48}$ Congregation for Institutes of Consecrated Life and Societies of Apostolic Life, Instruction: Fraternal Life in Community Congregavit Nos In Unum Christi Amor, Rome 04.02.1994, 12.

${ }^{49}$ Cf. ibid., 15. "Communal prayer reaches its full effectiveness when it is intimately linked to personal prayer. Common prayer and personal prayer are closely related and are complementary to each other. Everywhere, but especially so in some regions and cultures, greater emphasis must be placed on the inner aspect, on the filial relationship to the Father, on the intimate and spousal relationship with Christ, on the personal deepening of what is celebrated and lived in community prayer, on the interior and exterior silence that leaves space for the Word and the Spirit to regenerate the more hidden depths".

${ }^{50}$ Cf. John Paul II, Post-Synodal Apostolic Exhortation Vita consecrata, Rome 25.03.1996, 45. "I therefore exhort consecrated men and women to commit themselves to strengthening their fraternal life, following the example of the first Christians in Jerusalem who were assiduous in accepting the teaching of the Apostles, in common prayer, in celebrating the Eucharist, and in sharing whatever goods of nature and grace they had (cf. Acts 2: 42-47)."

${ }^{51}$ Cf. ibid., 51. "Such communities are places of hope and of the discovery of the Beatitudes, where love, drawing strength from prayer, the wellspring of communion, is called to become a pattern of life and source of joy." 
is the result of authentic love and expresses it, can bear fruit for the community of praying people. The Warsaw theologian justifies his analysis by referring to Fr. J. Woroniecki's claim that it is a "connection of human efforts in the act of prayer." 52 The central point is the meeting and experience of Jesus Christ. He becomes both the source and the goal of interpersonal communion, in which mutual intercession plays a huge role.

In this context, another aspect should be highlighted, which is the external witness of the praying community. It results from prayer and at the same time leads to its deepening. For this reason, following the thought of Fr S. Urbański, we should recognise the superiority of this type of prayer over individual or personal prayer. $^{53}$

\section{Practical Realization of Communal Prayer}

Common and communal prayer reveals its character in very concrete liturgical and paraliturgical (extra-liturgical) forms. ${ }^{54}$ In the practice of the Church and her believers it is a special gift and a challenge at the same time. The Church places liturgical prayer in the first place, as it is an expression of the prayers of all believers, with the reservation that: "the Church, $[\ldots]$ is ceaselessly engaged in praising the Lord and interceding for the salvation of the whole world. She does this, not only by celebrating the Eucharist, but also in other ways, especially by praying the divine office." 55 We have a great many studies on this subject, both on strictly theological grounds and in practical spirituality. Such prayer focuses primarily on the celebration of the sacraments and the Officium Divinum. ${ }^{56} \mathrm{In}$ the definitions of this type of prayer, theologians stress above all that it is a public worship performed by the Church and has an officially

\footnotetext{
52 Cf. S. Urbański, Teologia modlitwy, op. cit., p. 267; W.R. Macko, Rola $i$ znaczenie modlitwy w życiu świeckich, op. cit., p. 97.

${ }^{53} \mathrm{Cf}$. ibid.

${ }^{54}$ Cf. S. Witek, Teologia życia duchowego, Lublin 1986, p. 288; W.R. Macko, Rola i znaczenie modlitwy w życiu świeckich, op. cit., p. 101.

55 Constitution on The Sacred Liturgy Sacrosanctum Concilium (henceforward $\mathrm{SC}), 83$.

${ }^{56}$ Cf. J. Gogola, Teologia komunii, op. cit., p. 304.
} 
defined character. This means that the manner of worship has a strictly defined legal and liturgical framework and is not subject to change. Of course, in terms of content, it contains the essential forms such as thanksgiving, petition, supplication, praise and propitiation. Since this prayer is the prayer of the whole Church, it means that its fruits, as well as the consequences of its exercise or omission, affect the whole Mystical Body of Christ. For this reason, its effectiveness is not limited to individual believers or particular communities, but has the character of ex opere operantis Ecclesiae. ${ }^{57}$

As already signalled, the centre of the liturgical prayer of the Church is the celebration of the sacraments, culminating in the celebration of the Eucharist. ${ }^{58}$ It must therefore be said that sacramental prayer has a fundamental character in relation to all its other types and categories. This place and role are due to the nature of the sacraments themselves. Based on the statement of St. Augustine, who describes sacraments as signum rei sacra, in quantum est sacrificans hominem, ${ }^{59}$ we find that they perform in man what they signify, developing a supernatural reality in a successive manner. As St. Thomas Aquinas claims, together with sanctifying grace man also receives sacramental grace, which is related to the specificity of each sacrament. ${ }^{60}$ In the context of this issue, however, it is important to emphasise the reference to Christ as the Pre-sacrament and to the Church, which is "like a sacrament - a sign and instrument, that is, of communion with God and of unity among all men." ${ }^{61}$ The final formulation of the Council underlines the sanctifying, communion-creative nature of the sacraments. As the Church's teaching points out, "divine life is dispensed to us" through them and "they make present the graces." ${ }^{2}$ In this way we can clearly see that sacraments, having a personalistic dimension, are not only external and liturgical signs. They have a communiondialogical structure and character and in them the unification of man

${ }^{57}$ Cf. S. Urbański, Teologia modlitwy, op. cit., p. 245-254; S. Witek, Teologia życia duchowego, op. cit., p. 288.

${ }^{58}$ Cf. A. Zuberbier, Korzenie i natura modlitwy chrześcijan, op. cit. p. 43-45.

${ }^{59}$ STh III, q. 60, a. 2.

${ }^{60}$ Cf. STh III, q. 62, a. 2.

${ }^{61}$ CCC 775; A. Słomkowski, Teologia życia duchowego, op. cit., p. 69.

${ }^{62}$ CCC 1131. 
with God is achieved. Therefore, using contemporary theological language, which has its source in the teaching of the Council ${ }^{63}$ we can say that each sacrament individually and all together are a space of communion between man and God. Among them the Eucharist is the centre. ${ }^{64}$ It should be noted that this is the peak of the Christian's interpersonal encounter with God (cf. 1 Cor 10:16f), which bears the hallmarks of the most important union in temporal experience and at the same time has eschatological effects, i.e., its fruits reach the fullness of holiness (cf. Lk 22:14-23). A very important explanation in this regard can be found in the words of John Paul II: "Jesus himself assures us that this union, which creates by analogy with the union that takes place in Trinitarian life, is truly realised." 65 As a model he points to Mary and the analogy between her fiat and the human amen. ${ }^{66}$

Having in mind the prayerful nature of the sacraments, they cannot be treated only in liturgical and ritualistic terms, but above all in communion-creating and sanctifying categories. It is precisely

\footnotetext{
${ }^{63}$ Cf. LG 7.

${ }^{64}$ Cf. Decree on the Ministry and Life of Priests Presbyterorum Ordinis, (henceforward PO), 5. This is an extremely important statement from the point of view of the relationship between the sacraments: „The other sacraments, as well as with every ministry of the Church and every work of the apostolate, are tied together with the Eucharist and are directed toward it. The Most Blessed Eucharist contains the entire spiritual good of the Church".
}

${ }^{65} \mathrm{EE} 16$.

${ }^{66}$ Cf. ibid., 55. This papal analogy is so important and, at the same time, reflects the relationship in such a profound way that the whole passage is worth quoting: "The Eucharist, referring to the Passion and Resurrection, at the same time expresses continuity with the mystery of the Incarnation. In the Annunciation, Mary conceived the Son of God also in the physical truth of flesh and blood, anticipating in herself what is to some extent sacramentally realized in every believer who accepts in the form of bread and wine the Body and Blood of the Lord"; Ratzinger J., The Spirit of the Liturgy, San Francisco 2014. [Polish: Duch liturgii, transl. E. Pieciul, Poznań 2002, p. 28.] Cardinal Ratzinger, in an attempt to capture the reality of transformation and experience through the world of this sacredness, refers to Teilhard de Chardin and his interpretation of the Letter to the Ephesians and the Letter to the Colossuses. From this perspective, as Ratzinger claims: "The Transformed Host is, in his understanding, the anticipation of the transfiguration of matter and its divinity into a Christological 'fullness.' The Eucharist, in his view, sets the direction of cosmic movement: it anticipates the goal of the movement and, in pursuing the goal, evokes this movement." 
the prayerfulness that gives them their fundamental importance, making them a source and a means of dynamising the spiritual life of the Christian. Each sacrament, in its specificity of the grace it gives to a Christian, is an act of turning to God and, at the same time, His activity in human life. It is in this way that the sanctifying prayerful dialogue, which is the deepest nature of prayer, becomes a reality. ${ }^{67}$ According to $\mathrm{Fr}$ D. Wider, following Cardinal A. Bellestrero, "The prayer of the sacraments in its concrete form, filling with grace and nourishing with the Word of God, gives power and solid food. In this way it defends against sentimentalism." ${ }^{68}$ At the same time, the author points out the organic link between personal and sacramental prayer, stating: "[...] it makes it possible to give depth to the prayer of the sacraments through reflection and silent contemplation." 69

The Liturgy of the Hours, as has already been signalled, belongs to the Church's liturgical form of prayer, but at the same time has a deeply communal and often common character, i.e., it is celebrated in a group of praying people. The Catechism of the Catholic Church indicates its organic unity with the Eucharist, stating: "The mystery of Christ, his Incarnation and Passover, which we celebrate in the Eucharist especially at the Sunday assembly, permeates and transfigures the time of each day, through the celebration of the Liturgy of the Hours, 'the divine office'."70 The importance and weight of this prayer is reflected in the words of the Church's teaching: "[...] it is truly the voice of the bride addressed to her bridegroom; It is the very prayer which Christ Himself, together with His body, addresses to the Father."71 The Christocentric and thus Trinitarian dimension of this prayer points to its central place alongside the Eucharist. ${ }^{72}$ This truth is reflected in the explanation of the nature of this prayer provided in the Introduction, referring to

${ }^{67}$ Cf. CCC 2558; D. Wider, Zawsze się módlcie, op. cit., p. 127-128.

${ }^{68}$ D. Wider, Zawsze sie módlcie, op. cit., p. 128.

${ }^{69}$ Ibid.

${ }^{70}$ CCC 1174; D. Wider, Zawsze się módlcie, op. cit., p. 90.

${ }^{71} \mathrm{SC} 84$.

${ }^{72}$ Cf. CCC 1178; B. Mokrzycki, Kościól w świętości, Warszawa 1984, p. 257; M. Kunzer, Liturgia Kościoła, transl. L. Balter, Poznań 1999, p. 520; B. Nadolski, Liturgika. Liturgia i czas, vol. II, Poznań 1991, p. 241-242. 
Saint Augustine: "He prays for us and in us, and we pray to Him too. He prays for us as our priest; he prays in us because he is the Head of the Body that we are, and we pray to Him because He is our God. So we recognise our voices in Him, and His voice in us."73 This is a very clear picture of the communal character of this prayer, which is realised in the relationship between Christ and the praying Church and its individual members. Its biblical character should also be stressed in the mystery of communio that reveals itself through the experience of the Word in word and the inspiration of the Holy Spirit (cf. Gal 4:6; Rom 8:26-27). This communal character is directly emphasised by the Church in her teaching: "It is the 'public prayer of the Church,' in which the faithful (clergy, religious, and lay people) exercise the royal priesthood of the baptized. It is celebrated in 'the form approved' by the Church." 74 Therefore a salvific dialogue takes place in it and it ceases to be merely a private act of a Christian. It is a prayer that takes place in the Church, thanks to the Church and in the name of the Church. ${ }^{75}$ This aspect has extremely important consequences, because the fruits and effects of praying the Liturgy of the Hours concern the whole Church, as well as concrete particular communities. In it a Christian finds a model of perfect prayer. The General Introduction to the Liturgy of the Hours, referring to the Sacred Scriptures, indicates that it should be a prayer resulting from necessity, that is, a sense of responsibility for the grace that is the whole Church. Its next features are: humility, vigilance, continuity, trust. It must be based on an awareness of good intention, imbued with love and respect for God. Then it genuinely takes the form of prayer of praise, thanksgiving, petition and intercession. ${ }^{76}$ These are the characteristics of perfect prayer, which

${ }^{73}$ General introduction to the Liturgy of the Hours [Ogólne Wprowadzenie do Liturgii Godzin, Liturgia Godzin], vol. I, Poznań 1982, 7; Z. Nabzdyk, Modlitwa, op. cit., p. 127-128; A. Zuberbier, Korzenie i natura modlitwy chrześcijan, op. cit., p. $41-43$.

${ }^{74}$ CCC 1174.

${ }^{75}$ Cf. LG 24, 41; SC 86; A. Cencini, Oddech życia. Laska formacji permanentnej, transl. J. Zarzycka, Kraków 2003, p. 111; B. Mokrzycki, Kościót, op. cit., p. 257-258.

${ }^{76}$ General introduction [Ogólne Wprowadzenie], op. cit. 5; M. Kunzler, Liturgia, op. cit., p. 520-524. 
is effective, sanctifying the whole Church as well as the praying person. By its nature, it combines communal character and individuality. The effectiveness of this liturgical prayer, incorporated into the whole liturgy of the Church, therefore results from ex opere operantis Ecclesiae.$^{77}$ Following the teaching of the Second Vatican Council, we find that its communion-creative character affects the whole Church as well as individual communities which pray. It is especially ascribed to those who, because of their vocation to the consecrated and priestly life, are obliged to pray together in communities. Such a way of life dedicated to prayer is a gift for the whole Church and her apostolic work. ${ }^{78}$ It should also not be foreign to lay people who develop their spiritual life through formation in a movement or association. The Council Fathers recommend that the parish community be involved in this prayer: "Pastors of souls should see to it that the chief hours, especially Vespers, are celebrated in common in church on Sundays and the more solemn feasts. And the laity, too, are encouraged to recite the divine office, either with the priests, or among themselves, or even individually." 79

Theologians, when categorising prayer, conclude that, apart from liturgical prayer, also extra-liturgical prayer, sometimes referred to as paraliturgical prayer, which can take on an individual or collective character, should be included in communal prayer. ${ }^{80}$ In the present paper we are primarily interested in the latter dimension. The common celebration and experience of this kind of prayer is connected with the whole variety of services, liturgy of the word, common meditation, the practice of lectio divina. The extraordinary work of the Holy Spirit and the richness of the Church are revealed in this respect. We are dealing here with the broadly understood tradition of individual local Churches rooted in and living in the tradition of a nation or continent. Undoubtedly this character of

\footnotetext{
${ }^{77}$ Cf. S. Urbański, Teologia modlitwy, op. cit. p. 252.

${ }^{78}$ Cf. SC 95; General Introduction [Ogólne Wprowadzenie], op. cit. 2, 25

${ }^{79}$ SC 100; PC 7; General Introduction [Ogólne Wprowadzenie], op. cit. 27; John Paul II, Apostolic letter Novo Millenio ineunte, Rome 06.01.2001, 34.

${ }^{80}$ Cf. S. Urbański, Teologia modlitwy, op. cit. p. 266-267; S. Witek, Teologia życia duchowego, op. cit., p. 288.
} 
prayer is most clearly associated with groups of priestly formation, consecrated life ${ }^{81}$ as well as the laity. ${ }^{82}$

Common prayer, as has already been pointed out, is of particular importance and expresses the fact that the praying persons harmoniously address God, who is the principle but also the raison d'être of this act. It is He who, by His grace, through the action of the Holy Spirit, initiates and constitutes the community (cf. Matt 18:19; Rom 12:4-8). This means that the quality of life of those who pray together finds its reference to God. Love for God transferred to the level of interpersonal relationships (cf. Mk 12:28b-34; 1 Jn 4:7-12), building a real unity, becomes the essential communion-creative factor. Following the analysis undertaken by Fr. Z. Nabzdyk, we find that this type of prayer, in anthropological terms, allows man to go beyond the framework of his individuality. This applies both to the form itself as well as to the intention and direction. ${ }^{83}$ This means that the development of authentic devotion takes place simultaneously on two levels: individual and communal. By being compatible and complementary to each other, they make the Christian's prayer life develop correctly and be less prone to distortion and deviation in this regard. In this way, its supernatural effectiveness is increased, as stressed by St. Thomas Aquinas, ${ }^{84}$ but at the same time it becomes a living testimony and an appropriate response to contemporary secular trends, continuing God's work through consecratio mundi. ${ }^{85}$

${ }^{81}$ Cf. S. Witek, Teologia życia duchowego, op. cit., p. 288.

${ }^{82}$ Cf. John Paul II, Post-Synodal Apostolic Exhortation Christifideles Laici, Rome 30.12.1988, 16. In his teaching, the Pope states very clearly the nature of liturgical and paraliturgical prayer in the sanctifying life of the laity in words: "Life according to the Spirit, whose fruit is holiness (cf. Rom 6:22; Gal 5:22), stirs up every baptized person and requires each to follow and imitate Jesus Christ, in embracing the Beatitudes, in listening and meditating on the Word of God, in conscious and active participation in the liturgical and sacramental life of the Church, in personal prayer, in family or in community, in the hunger and thirst for justice, in the practice of the commandment of love in all circumstances of life and service to the brethren, especially the least, the poor and the suffering"; CCC 901.

${ }^{83}$ Cf. Z. Nabzdyk, Modlitwa - źródło i wyraz duchowości, op. cit., p. 133.

${ }^{84}$ Cf. STh II-II, q 83, a. 7.

${ }^{85}$ Cf. LG 1. 


\section{Bibliography}

Balthasar H. Urs von, Teologika. Duch Prawdy, vol. 3. transl. J. Zychowicz, Kraków 2005.

Catechism of the Catholic Church, https://www.vatican.va/archive/ENG00 15/_INDEX.HTM.

Cencini A., Oddech życia. Łaska formacji permanentnej, transl. J. Zarzycka, Kraków 2003.

Chmielewski M., Vademecum duchowości chrześcijańskiej, Lublin 2004.

Communio, in: Słownik tacińsko-polski, ed. J. Korpanty, Warszawa 2001, p. 126.

Congregation for Institutes of Consecrated Life and Societies of Apostolic

Life, Instructio de Vita Contemplativa et de Monialium Clausura Venite seorsum, 15.08.1969, http://www.vatican.va/roman_curia/con gregations/ccscrlife/documents/rc_con_ccscrlife_doc_19690815_de-v ita-contemplativa_lt.html.

Congregation for Institutes of Consecrated Life and Societies of Apostolic Life, Instruction: Fraternal Life in Community Congregavit Nos In Unum Christi Amor, 04.02.1994, http://www.vatican.va/roman_curia/ congregations/ccscrlife/documents/rc_con_ccscrlife_doc_02021994_f raternal-life-in-community_en.html.

Cynarzewska-Wlaźlik L., Wspólnota. W naukach społecznych, in: Encyklopedia katolicka, vol. XX, Lublin 2014, col. 1001-1002.

De Mattei R., Dyktatura relatywizmu, transl. P. Toboła-Pertkiewicz, E. Turlińska, Warszawa 2009.

Gogola J., Teologia komunii z Bogiem, Kraków 2001.

Góźdź K., Teologia człowieka, Lublin 2006.

Granat W., Personalizm, Personalizm chrześcijański. Teologia osoby ludzkiej, Lublin 1982.

Guardini R., Vorschule des Betens, Leipzig 1960.

Jagodziński M., Communio dzięki komunikacji. Teologiczny wymiar teorii komunikatywnego działania w eklezjologii Medarda Kehla SJ, Radom 2002.

Jagodziński M., Sakramenty w stużbie communio, Warszawa 2008.

John Paul II, Apostolic Letter Novo Millennio ineunte, 06.01.2001, http://www.vatican.va/content/john-paul-ii/en/apost_letters/2001/do cuments/hf_jp-ii_apl_20010106_novo-millennio-ineunte.html.

John Paul II, Encyclical Letter Ecclesia de Eucharistia, 17.04.2003, vatican.va/content/john-paul-ii/en/encyclicals/documents/hf_jp-ii_ enc_20030417_eccl-de-euch.html. 
John Paul II, Post-Synodal Apostolic Exhortation Christifideles Laici, 30.12.1988, http://www.vatican.va/content/john-paul-ii/en/apost_exh ortations/documents/hf_jp-ii_exh_30121988_christifideles-laici.html.

John Paul II, Post-Synodal Apostolic Exhortation Ecclesia in Europa, Rome 28.06.2003, http://www.vatican.va/content/john-paul-ii/en/apos t_exhortations/documents/hf_jp-ii_exh_20030628_ecclesia-in-europa .html.

John Paul II, Post-Synodal Apostolic Exhortation Vita consecrata, 25.03.1996, http://www.vatican.va/content/john-paul-ii/en/apost_exh ortations/documents/hf_jp-ii_exh_25031996_vita-consecrata.html.

Kowalczyk S., Zarys filozofii człowieka, Sandomierz 1990.

Kunzer M., Liturgia Kościoła, transl. L. Balter, Poznań 1999.

Ladaria L.F., Wprowadzenie do antropologii teologicznej, transl. A. Baron, Kraków 1997.

Macko W.R., Rola i znaczenie modlitwy $w$ życiu świeckich $w$ świetle nauczania kard. Stefana Wyszyńskiego, "Collectanea Theologica" 76 (2006) no 1, p. 93-102.

Mielcarek K., Wspólnota, in: Encyklopedia katolicka, vol. XX, Lublin 2014, col. 999-1000.

Mikołajewska B., Zjawisko wspólnoty, New Haven 1999.

Misiurek J., Modlitwa. Medytacja. Mistyka, Lublin 2011.

Mokrzycki B., Kościót w świętości, Warszawa 1984.

Nabzdyk Z., Modlitwa - źródło i wyraz duchowości, in: Teologia duchowości katolickiej, eds. W. Słomka, M. Chmielewski, J. Misiurek, A.J. Nowak, Lublin 1993, p. 124-147.

Nadbrzeżny A., Wspólnota. $w$ teologii, in: Encyklopedia katolicka, vol. XX, Lublin 2014, col. 1000-1001.

Nadolski B., Liturgika. Liturgia i czas, vol. II, Poznań 1991.

Ogólne Wprowadzenie do Liturgii Godzin, Liturgia Godzin, vol. I, Poznań 1982.

Pallotti Wincenty, Wybór pism, vol. IV, transl. F. Bogdan, Ząbki 2001.

Piłat-Borcuch M., Pomiędzy tożsamościa osobowa a postawa społeczna, “Zeszyty Naukowe Politechniki Śląskiej” (2013) no. 65, p. 317-327.

Ratzinger J., Duch liturgii, transl. E. Pieciul, Poznań 2002. [English: Ratzinger J., The Spirit of the Liturgy, San Francisco 2014.

Sartre J.P., L'être et le néant, Paris 1943.

Scola A., Osoba ludzka. Antropologia teologiczna, transl. L. Balter, Poznań 2005.

Second Vatican Council, Constitution on The Sacred Liturgy Sacrosanctum Concilium, http://www.vatican.va/archive/hist_coun 
cils/ii_vatican_council/documents/vat-ii_const_19631204_sacrosanct um-concilium_en.html.

Second Vatican Council, Decree on The Ministry and Life of Priests Presbyterorum Ordinis, http://www.vatican.va/archive/hist_councils/ ii_vatican_council/documents/vat-ii_decree_19651207_presbyteroru m-ordinis_en.html.

Second Vatican Council, Dogmatic Constitution on The Church Lumen Gentium, http://www.vatican.va/archive/hist_councils/ii_vatican_cou ncil/documents/vat-ii_const_19641121_lumen-gentium_en.html.

Second Vatican Council, Pastoral Constitution on The Church in the Modern World Gaudium Et Spes, http://www.vatican.va/archive/hist_ councils/ii_vatican_council/documents/vat-ii_const_19651207_gaud ium-et-spes_en.html.

Skrzypczak R., Kościót jako misterium, communio i missio, "Warszawskie Studia Teologiczne” XVII (2004), p. 167-184.

Ślipko T., Zarys etyki szczegółowej, vol. 2. Kraków 1981.

Słomkowski A., Teologia życia duchowego, Ząbki 2000.

Stabińska J., Wincenty Pallotti, Poznań 1982.

Tatar M., Od duszy artysty do artyzmu ducha, "Collectanea Theologica," 84 (2014) no 1, p. 109-122.

Thomas Aquinas, Summa Theologica, New York (NY) 1947.

Urbański S., Teologia modlitwy, Warszawa 1999.

Warzeszak J., "Dyktatura" relatywizmu w ujęciu Benedykta XVI, "Warszawskie Studia Teologiczne," XXIV (2011) no. 1, p. 291-322.

Wider D., Zawsze się módlcie, Kraków 1999.

Witek S., Teologia życia duchowego, Lublin 1986.

Zuberbier A., Korzenie i natura modlitwy chrześcijan wedtug "Katechizmu Kościoła Katolickiego", "Collectanea Theologica," 65 (1995) no. 2, p. 37-47. 